\title{
Together towards life and mission: A basis for good governance in church and society today
}

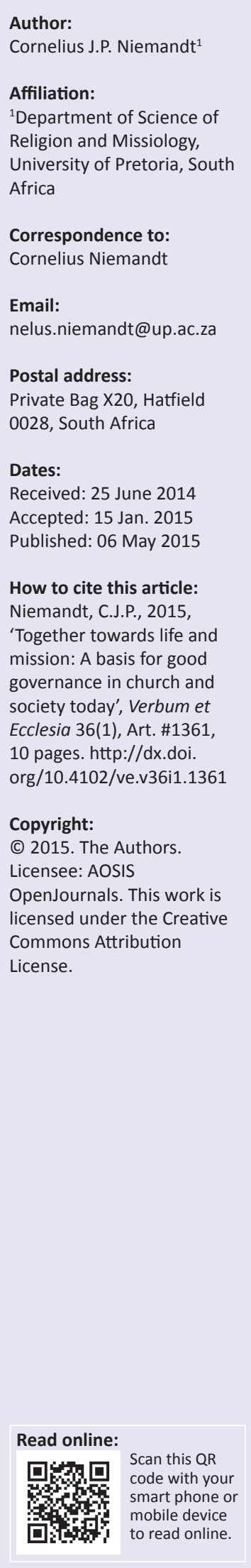

In this research, important policy decisions by the 2013 General Synod of the Dutch Reformed Church on the missional nature of the church were investigated in dialogue with the new mission affirmation of the World Council of Churches Together towards life: Mission and evangelism in changing landscapes (2013). The research concluded that the new policy document of the Dutch Reformed Church in South Africa (DRC) shows convergence with TTL and that the DRC finds itself within the current ecumenical discourse on church and mission. The DRC does have a comprehensive missional ecclesiology, understanding the church as missional by its very nature. Church polity is informed by a missional understanding of being church. The DRC shows good governance in the sense that it has embarked on a process to revise the church order in the light of the policy decisions and in the sense of the foundation laid by revising a number of important articles of the church order. The research also found that a missional approach affirms life in its fullness and allows and participates in the flourishing of creation. The deduction was that good governance in society entails a society where justice is practised, sustainable lifestyles propagated and respect for the earth practised. The DRC, with its missional understanding of being church, can benefit in its discernment processes and prophetic witness by using an appropriate hermeneutical key in its participation in good governance - to discern where life in its fullness is affirmed. The research found that the DRC finds itself, together with a broader ecumenical community, on a journey towards life. It does have an appropriate basis for good governance in church and society.

Intradisciplinary and/or interdisciplinary implications: The research calls for a change in the traditional discourse on the role of denominations and brings together insights from ecumenical studies and missional ecclesiology that might assist the reformulation of church polity.

\section{Introduction}

\section{Good governance depends on the nature of the church}

In what way is good governance in church and society related to the nature of the church? Does a missional ecclesiology present an appropriate basis for good governance in the church? What is the impact of such missional ecclesiology on good governance in society? Where does the Dutch Reformed Church in South Africa (DRC) stand in relationship to these issues? The following research questions flows from the above: Does the DRC have a formulated missional ecclesiology, and is this ecclesiology ecumenically relevant? How does this ecclesiology inform DRC church polity?

These questions are explored by investigating recent important policy decisions by the General Synod of the DRC on the missional nature of the church and the impact of these decisions on the formulation of an appropriate church polity. This is done in relation to a new mission affirmation by the World Council of Churches (WCC 2013b), Together towards life: Mission and evangelism in changing landscapes (TTL). The WCC affirmation is especially relevant since the DRC has returned to the WCC as a full member after an absence of nearly 60 years. The DRC policy document, Raamwerkdokument oor die missionale aard en roeping van die NG Kerk [Framework document on the missionale nature and calling of the DRC] (Nederduitse Gereformeerde Kerk [NGK] 2013a:199-215), refers to and builds on the WCC affirmation, and this research will investigate convergence between these two documents as well as note where the DRC goes beyond TTL. (As TTL precedes the DRC policy document, the presumption is that TTL was not influenced by the policy document, and cases where TTL goes beyond the DRC will not be discussed.) This research is done from a missiological perspective, claiming that all theology has to be missiological (Bevans 2010:10; Flett 2010:295), acknowledging the importance of a multi-disciplinary approach and thus recognising the role of theological disciplines such as church polity, church history and practical theology. It is especially done with appreciation for the relationship between 
ecclesiology and church polity and keeping in mind the statement by Koffeman (2014:8) that church polity needs to be informed by normative ecclesiology and that church polity must be ecumenical (Koffeman 2014:10). It must be explicitly stated that research into the missional praxis of DRC congregations falls beyond the scope of this research. Although the life, work and witness of the church is very important, the research follows Coetzee and Conradie's (2012:2) description of six manifestations of church (sermons, leadership decisions on local congregational level, synods, ecumenical meetings, the experiences and praxis of members of the church and theological debates) and focuses on two of these manifestations: leadership decisions on the level of the DRC General Synod and decisions of ecumenical meetings. This approach flows from the understanding that these policy decisions create a missional language and represent a particular kind of story that is able to shape the missional imagination of a denomination such as the DRC. Roxburgh (2011:57-62) and Branson (2007:95) applied Taylor's concept of social imaginaries (Taylor 2004) to the missional church, and my research builds on the way in which policy decisions can shape the language, imagination and eventually practises of a church (see also Niemandt 2013:122-126).

\section{The church governs what is does and does what it is}

In what way is good governance related to the nature of the church? This means that the relationship between good governance in the church and the nature of the church as well as the way in which good governance reflects the missional nature of the church must be investigated.

Church governance and polity must reflect ecclesiology. Koffeman (2012:11-13) made a sound case for the relationship between church polity and theology. Church polity serves the church and the theology of a specific church. He argues that church polity is based on the theological vision of a church in a specific community and at a specific time. Church polity reflects a theological position on ecclesiology. This is, however, an open-ended relationship because the church is always contextual and must be church of Jesus Christ in changing landscapes and contexts. The nature of the church provides the framework to understand the character of the church. What the church is determines what the church does. The purpose of the church and the direction and scope of its ministries are determined by the nature and character of the church. The church organises what it does and agrees on rules that regulate ministries and organisation (Van Gelder 2007:18). Issues, such as the way in which the church organises and governs what it does, need to be answered against this background. Church polity and organisation, as well as leadership, must reflect the identity, calling, life and order of the church. Ecclesiology is the architecture of the life of the church (Dingemans 1987:9).

Issues related to ecclesiology and good governance is discussed in the context of the missional church. The church is missional. The church is in a permanent state of mission. Mission is at the heart of what it means to be church (Dingemans 1987:41). Bevans and Schroeder (2011:13-16) say that God has a mission, and his mission has a church. Mission precedes the church and calls the church into being to serve God's purposes in the world. The church participates in the missio Dei and is a church which always goes forth with a missionary joy - the church is a community of missionary disciples (Evangelii Gaudium 2013:20, 21). Dreyer (2014) argues as follows:

Missional ministry emphasises a living relationship with God, real faith, a focus on the kingdom of God, a relevant ministry, discernment through the Holy Spirit, a systematic approach of congregational development, a focus on people and relationships, and discipleship. (p. 42)

This must be reflected in the church order. Good governance and the prophetic witness of the church towards society are determined by the broader ecclesiological framework of what the church is. Koffeman's (2014:12) plea must be supported, namely that '... we really need a missionary approach of church polity'.

Good governance entails a church polity that is conducive towards the transformation of the church into missional life. One can say that ecclesiology determines the quest for good governance in church and society. What kind of ecclesiology (what the church is) might assist the church in these times of changing landscapes and the dominant liminality in society? If the church does what it is and then organises what it does, it entails clearly a challenge of design or architecture.

Koffeman states that the current context and changing landscapes must challenge churches of the Reformation to acknowledge that the marks of the church (notae ecclesiae) and specifically the 'pure preaching of the gospel' - are not so much about the confessions of faith as about the missional nature of the church. 'The way in which the church pays attention to dialogue with the culture determines the quality of the church and congregations' (Koffeman 2012:191). This true nature of the church must be reflected in church polity, and church polity must lead the way in giving congregations permission to be truly missional and equipping them to participate in God's mission (Koffeman 2012:200). The same intention is clear in Evangelii Gaudium (2013:25) where Pope Francis exhorts the church that the missionary impulse must transform everything so that the church's customs, ways of doing things, times and schedules, language and structures can be suitably channelled for this missional goal.

To summarise, missional ecclesiology presents an appropriate basis for good governance in the church (church polity), and church polity must serve a missional ecclesiology.

\section{Missional church and good governance in society}

What is the impact of a missional ecclesiology on good governance in society? The missional nature of the church provides an important clue to the relationship between a 
missional church and society. The very being of a missional church is to participate in the mission of God. Mission is God's movement towards his creation and began with the act of creation. Mission calls the church into being to serve God's purpose in the world.

God created everything and created life to flourish. Although creation has fallen in the midst of the presence of sin, the horizon of God's redemptive re-creation is still the word (Van Gelder 2007:57). Mission proclaims a new way of thinking about all of creation, including human beings, earth's creatures and created universe itself (Bevans \& Schroeder 2004:376). The mission affirmation of the World Council of Churches (WCC 2013b), TTL, puts it clearly:

Rather the gospel is the good news for every part of creation and every aspect of our life and society. It is, therefore, vital to recognize God's mission in a cosmic sense, and to affirm all life, the whole oikoumene, as being interconnected in God's web of life. (p. 52)

Mission affirms life in its fullness. Mission allows and participates in the flourishing of creation. Good governance in society brings about a society where justice (i.e. ecological, gender and economical) is practised, sustainable lifestyles propagated and respect for the earth practised, particularly in the liturgy of the church. The WCC provides a very important hermeneutical key to the church in its prophetic witness towards society and in its participation in good governance: Wherever life in its fullness is affirmed and exists in all its dimensions, including the liberation of the oppressed, the healing and reconciliation of broken communities and the restoration of creation, we discern the Spirit of God bringing life. Wherever forces of death and destruction of life prevail, we discern opposition to God's life-giving mission (WCC 2013b:56). This hermeneutical key guides the process to discern what good governance might entail in today's changing landscapes.

What is the impact of a missional ecclesiology on good governance in society? The impact of missional ecclesiology is that it provides a hermeneutical key to discern the missio Dei and, particularly, the missio Spiritus. TTL (WCC 2013b:52) puts it as follows: 'The church is commissioned to celebrate life, and to resist and transform all life-destroying forces, in the power of the Holy Spirit.' Good governance is where life flourishes. Good governance must be conducive towards and safeguard life in its fullness. Good church governance facilitates prophetic witness towards civil society, politics and the economy about the true life to be found in God's kingdom.

\section{A turning point in developing a missional ecclesiology in the Dutch Reformed Church}

Where does the DRC stand in relationship to these issues? Does the DRC have a formulated missional ecclesiology, and is this ecclesiology relevant in terms of current discourse in the international ecumenical movement such as the World Council of Churches?

This discussion and the development of a missional language are done in dialogue with ecumenical insights. Koffeman (2012:45) perhaps overstates ecumenism when he argues that '... church polity must be ecumenical and not confessional'. He says that church polity is ecumenical in nature (Koffeman 2014:9). Dingemans (1987:20) also lauded an ecumenical approach to ecclesiology and placed this in the broadest sense of the term 'ecumenism' as the whole creation and household of God. In the development of church polity, the ecumenical aspect can serve as a focal point instead of confessional tendencies, which create distinctiveness, separation and boundaries and present itself as stumbling blocks to church unity. However, the issues of identity and tradition must be balanced with the ecumenical focus to assist churches to be church with other churches. The development of a missional ecclesiology in the DRC is therefore investigated against the backdrop of a growing ecumenical consensus on the missional nature of the church.

Is the 'governance' or polity of the DRC is in harmony with a missional ecclesiology? The answer to this question is given in relationship to the mission affirmation of the WCC (2013c), Together towards life. TTL is presented in a dialogue with the policy document of the DRC and covers points of convergence. In this approach, my research falls within the parameters set by Koffeman (2014:9) when he stated that both church polity and ecumenical life show that churches are involved in a movement that is rooted in the mission of God and orientated towards the kingdom of God.

A new missional ecclesiology is establishing itself in the DRC. The 2011 policy document, Missional ecclesiology, was the culmination of a discernment process that developed over nearly 9 years (NGK 2011a:130-141). It is a significant development in DRC ecclesiology and polity and is itself a full-fledged ecclesiology (Niemandt 2014:73). The origin of the aforementioned Missional ecclesiology can be traced back to the 2002 General Synod of the DRC when synod decided to ask its commission focussing on congregations to study the issue of a practical congregational ecclesiology (NGK 2002a:542). This request was extended in 2004 (NGK 2004:444). The report was tabled at the synod of 2011 (NGK 2011a, 2011b). The General Synod decided to extend the study process and requested a new combined report that consolidated a number of reports tabled at the 2011 General Synod. The final report, compiled and written by Prof. P.G.J. (Piet) Meiring and Prof. C.J.P. (Nelus) Niemandt, included input from four reports tabled at the 2011 General Synod: (1) Missionale ekklesiologie [Missional ecclesiology], (2) die Kerk en die konteks [Church and context], (3) Evangelisasie [Evangelism] and (4) Diversiteit [Diversity].

These developments represent a turning point in the development of a missional ecclesiology in the DRC and laid the foundation for the acceptance of a policy document 
on the missional nature and calling of the DRC at the 2013 General Synod.

\section{The missional ecclesiology of the Dutch Reformed Church}

A new policy document, called Raamwerkdokument oor die missionale aard en roeping van die NG Kerk, was tabled in 2013 (NGK 2013a), and accepted by synod (NGK 2013b). The goal of the report was stated as the creation of new missional language that may ignite new imagination for the DRC (NGK 2013a:200). The formulation of the acceptance of the policy document is quite interesting (NGK 2013b):

21.1 General Synod received the policy document as a document that expresses the discernment processes over the last ten years in the Dutch Reformed Church. These processes paid attention to the essence and nature of the church and its witness in the world. The General Synod accepted the document as part of a conversation that assists the denomination to create new (missional) language, facilitating new conversations and imaginative new possibilities for the future of the church. (p. 8)

Many of the 'contours of an emerging missional ecclesiology' (see Niemandt 2010:92-103) identified in the 2011 document Missional ecclesiology, became firmly established (NGK 2011a:130-141). The following serves as a summary of the new missional ecclesiology in the DRC. Care is taken to present it in dialogue with TTL to allow an ecumenically relevant approach.

\section{Reformed identity}

The missional ecclesiology is built on an understanding of the DRC's identity as a reformed church, shaped by the four well know sola's of reformed identity and motivated by the dictum ecclesia reformata semper reformanda. The church, being understood as a missional church, constantly rethinks its ministry and the contextualisation of the gospel in the light of changing landscapes. Reformed identity also places the DRC in a 'life in the Triune God'. This clear statement on the identity of the DRC was influenced by an important document on reformed identity accepted at the 2007 General Synod (NGK 2007a:14).

\section{New insights in the understanding of God}

The framework document represents a recalibration of the DRC's understanding of God - labelled 'New insights in God'. Trinity introduces us to a sending God who is a missionary God. Mission is understood as an activity of the triune God, Creator, Saviour and Redeemer for the sake of the world and in which the church is privileged to participate. The relationship of God to creation is described in Trinitarian terms. The mission of God is the continuation of the work started at creation towards the eschaton, a new, glorious heaven and earth where God will be all in everything and where Jesus the Christ is the Eschaton, the very embodiment of God's original intention with all of creation. The acknowledgement of the important role of the
Holy Spirit is striking: '... the Holy Spirit accompanies the church as God's light bearer and guide towards creation's destiny' (NGK 2013a:202).

In terms of understanding this approach in dialogue with a growing ecumenical consensus, it must be noted that there is significant convergence with TTL. The Trinitarian foundation is stated in the very first words: 'We believe in the Triune God who is the creator, redeemer and sustainer of all life' (WCC 2013b:51). This is followed by: 'Mission begins in the heart of the Triune God and the love which binds together the Holy Trinity overflows to all humanity and creation' (WCC 2013b:51). Mission is the overflow of the infinite love of the Triune God (WCC 2013b:52). One of the significant characteristics of TTL is the emphasis on the work of the Holy Spirit within the missio Trinitatis. The main thrust of the WCC's mission affirmation is indeed on the work of the Holy Spirit. The essence of mission is a life in the Holy Spirit (WCC 2013b:51), which is discussed under the following headings:

- spirit of mission: breath of life

- spirit of liberation: mission from the margins

- spirit of community: church on the move

- spirit of Pentecost: good news for all.

The DRC policy document does not have such a strong emphasis on the missio Spiritus. The DRC refers to God's mission carried out through the sending of Christ and the Spirit (NGK 2013a:202) but certainly differs from the strong focus in TTL.

\section{An affirmation of the Missio Dei}

The DRC framework document has a clear statement on the missio Dei. The Trinity is a community of love flowing towards the whole of creation and inviting all of creation into community with the Trinity. In as much as we say that 'God is love', we say that 'God is a sending (missionary) God'. The life of the Trinity is a missional life, and the communion in the Trinity is a communion that flows outward. This provides the framework for Christian mission as the proclamation of the kingdom of the Father, to share the love of Jesus Christ with all and to be witnesses of the powerful work of the Spirit. The missio Dei defines the essence and substance of the church. The missio Dei is at the core of being church. The church focuses on the world and is directed towards the world because the church does not exist for the sake of its members or itself. This provides the framework to define, describe and order the church in terms of its mission to the world. Mission defines the essence of the church. Therefore it ought to determine the teaching, liturgy and confessional nature of the church.

In reading the DRC policy document against the ecumenical backdrop of TTL, the broad acceptance of the idea of the missio Dei becomes clear. TTL points to God's mission in stating (WCC 2013b):

God's mission points to the belief in God as One who acts in history and in creation, in concrete realities of time and contexts, 
who seeks the fullness of life for the whole earth through justice, peace and reconciliation. (p. 60)

God is a missionary God who sent the Son to the world and calls all of God's people and empowers them to participate in God's mission.

\section{New insights in the church: The missio Dei leads to the missiones ecclesiae}

The church is understood as missional by its very nature. The Triune God invites the church to participate, through Jesus Christ, in God's mission. The document affirms (NGK 2013a):

We believe that the church belongs to God and exists only in union with God. The church is the people of God, the body of Christ and a temple of the Spirit. (p. 202)

The church is a missional church and participates in God's mission. This is the goal, origin and essence of the church and is even continued in eternity where the church will still reach out to and serve others. Mission is the very life of the church. The DRC, as a missional church, is a community gathered, formed, equipped and sent to proclaim the love of God. The document elaborates on the way in which the church participates in God's mission and uses concepts of leitourgia (worship), koinonia (communion of the faithful), kerugma (proclamation) and diakonia (service) to explain the holistic nature of the church's mission. In this sense, the DRC goes beyond TTL.

The issue of unity and diversity, and unity in diversity, receives particular attention within this missional framework. The unity in the Trinity is the base of the unity within the diversity of the church, a case of the church being imago Trinitatis. The imago trinitatis has very important implications for ecclesiology, church polity and good governance. It guides the church in understanding the relationships within the Trinity, the relationships between people and the relationship between church and world. From this point of view, unity can be seen as a gift and imperative, and unity serves diversity (and good governance) by nurturing mutual respect and the crossing of boundaries. The DRC framework document refers to the 2007 Statement of Calling and continues: 'We are aware of our diversity, but committed to greater unity within the church, to the reunification of the DRC church family, as well as strengthening our ecumenical ties' (NGK 2007b).

When one brings this approach of the DRC in dialogue with the WCC, the similarities with the underlying ecclesiology of TTL are clear: The life of the church arises from the love of the Triune God (WCC 2013b:63). God indwells the church through Christ in the Holy Spirit and reveals God's mission to the world, empowering and enabling the people of God to participate in the missio Dei. TTL (WCC 2013b:63) states: 'The church exists by mission, just as fire exists by burning. If it does not engage in mission, it ceases to be church.'
Mission and unity belong together. The authenticity and credibility of the Gospel depends on mission in unity. The church is an inclusive community that welcomes all. The emphasis on the work of the Holy Spirit is also evident when TTL affirms that the Holy Spirit is the Spirit of unity. The Holy Spirit unites people and churches to celebrate unity in diversity (WCC 2013b:65).

The DRC goes beyond TTL in the formulation of values that serve as an imaginative framework for further creative thinking about the missional nature of the church. The following values for a missional church are mentioned: The church focuses on the Triune God, the church is sent to the world and does not focus on its own survival, the church incarnates the gospel and the church transforms the community and brings about change. The church makes disciples, the church cherishes relationships and unity, and the church practices a kenotic existence (NGK 2013a:203).

\section{New insights in the kingdom of God}

Reformed faith appreciates the fact that God's kingdom is much broader than the church. The people of God are called to set up signs of the kingdom and to live in such a way that they testify to the reign of God. Kingdom living must be evident in everyday life and can be described as earthy and natural. The church must exhibit kingdom life and God's love. The 2007 Statement of Calling is cited with approval when it states: 'Called as believers, we are salt for the earth and light for the world. We are servants of God's coming kingdom' (NGK 2007b:1).

The policy document dismisses the idea of a church-shaped kingdom as well as a world-shaped kingdom and rather talks about a kingdom-shaped church - a church formed and informed by the ideal of God's kingdom (NGK 2013a:204).

In TTL, the church is described as a 'gift of God' to the world for its transformation towards the kingdom of God. The mission of the church is to bring new life and to announce the loving presence of God in our world (WCC 2013b:53). The church must be a sign of hope and an expression of the kingdom of God here on earth (WCC 2013b62-63). The mission affirmation connects mission and kingdom when it states: 'Mission-as a common witness to Christ-is an invitation to the "feast in the kingdom of God"' (WCC 2013b:73).

The DRC states that Reformed people have always recognised that the Kingdom is greater and more far-reaching than the church. It goes beyond TTL in referring to the church as a sacrament, a foretaste of what God's kingdom is here on earth. The document rejects a 'church-shaped kingdom' as well as a 'world-shaped kingdom' and chooses a 'kingdomshaped church' (NGK 2013a:204).

\section{New insights in incarnational theology}

One of the significant issues in the 2013 framework document is the expanded and more comprehensive statement on the 
incarnation (NGK 2013a:202). It starts with a description of the incarnation of Jesus Christ as a special 'explanation' of God's mission and God's love for all of creation. Self-giving typifies the life of the Trinity, and self-giving is at the heart of the divine mission to the world. The incarnation also serves as a model for the church. Incarnation is to be present with people wherever they may find themselves. To be present does not imply that the tension between kingdom and world is released but rather that it is understood as a creative a productive tension.

The document has an interesting discussion on kenosis. Kenosis is the opposite of self-assertion and self-fulfilment. It is all about sacrifice and self-sacrifice, about participating in the self-sacrificing nature of the Triune God to bring healing and new life. It is a way of living and approaching life - to be missional is to be vulnerable for the sake of others (NGK 2013a:205)

The kenotic praxis is explained by the following concepts:

- Presence - A missional church is a movement to others, outsiders and the world. It is a relational concept that values koinonia.

- Proximity - This means to be so close to others in such a way that things can be understood from their point of view. It is an empathic process.

- Powerlessness - The usual power structures do not serve the mission of the church. The church is about humility and self-sacrifice for the sake of others.

- Proclamation - The incarnation of Jesus Christ is the Gospel. An incarnational approach understands the life of self-sacrifice and service to others.

TTL (WCC 2013b:64) has a beautiful statement on kenosis:

Jesus became our Christ not through power or money but through his self-emptying (kenosis) and death on the cross. This humble understanding of mission does not merely shape our methods, but is the very nature and essence of our faith in Christ. The church is a servant in God's mission and not the master. The missionary church glorifies God in self-emptying love. (p. 64)

TTL refers to the ministry of Jesus who became our Christ not through power but through his self-emptying (kenosis) and death on the cross. The document states that this grounding of mission in the self-emptying love of Jesus leads to a humble understanding of mission. Mission is a movement taking place from the centre to the periphery and from the privileged to the marginalised of society. This is why mission from the margins receives so much attention (WCC 2013b:52, 58-60). The kenotic approach shapes our methods, but much more - this is the true nature of a missional church. Even more, it '.. is the very nature and essence of our faith in Christ' (WCC 2013b:64).

The DRC framework document converges with the broader ecumenical understanding concerning the recognition of the importance of kenosis and humble self-emptying. The DRC echoes TTL in recognising that kenosis is at the very heart of a missional ecclesiology. It concludes (NGK 2013a:205): ‘To empty yourself for the sake of the community to which God has sent us, that is the way that each congregation must walk in its following of Christ.'

\section{New insights in context}

In the section on context and the world, the DRC recognises the theological imperative of contextualisation and inculturation. The discussion on incarnation sets the scene precisely because the incarnation is a key paradigm for contextualising the church. The life of the church as life in the Trinity, and the fundamental importance of the incarnation as a movement towards where people are, demands an appreciation of the world and the context. The policy document does this in six movements (NGK 2013a:206):

- The church finds itself and is being sent to God's world.

- God the Creator created the world. All contexts are good. The context must be appreciated with a sense of wonder, celebration and thanksgiving.

- God's mission is to bring all of creation to its ultimate destination. Creation is incomplete, but God's preferred future is breaking in and creating expectation and hope.

- Although creation is marred by sin, every context is under God's merciful judgement. Although the power of sin puts in every effort to thwart the missio Dei, nothing can stop God's mission to redeem creation, even if it demands the ultimate sacrifice.

- Because sin is unable to thwart God's mission, hope prevails in each and every context. There is a future God's future. There is hope - the missio Dei cannot be stopped. The created world is the redeemed world and the world in the process of being recreated.

- The hermeneutical key to a missional existence is to be able to discern God's work in each and every context. Discernment is the first step in mission. The challenge, and joy, of the church is to discern the work of the Holy Spirit in every context and to join in with the Spirit.

The surprising convergence between the framework document and TTL is evident, and the very title of the WCC affirmation states the importance of contextualisation when the subtitle talks about 'Mission and evangelism in changing landscapes'. The document recognises that the context of missional activity influences its scope and character. Therefore the social location and contextual realities of all those engaged in mission work must be taken into account (WCC 2013b:59, 66).

\section{New insights in congregations}

Text and context interact in congregational life. God is actively working in creation as well as in the local church. Congregations are the basic building blocks of the church. The emphasis is not so much on the institution as on local expressions of the body of Christ, not so much on larger structures such a synods as on the local churches. The primary existence of the church is on local level. The DRC 
policy document describes the church as a movement, and church 'happens' in everyday life. As much as the church can be described as a missional church, local congregations ought to be described as missional congregations. They must be permeated with God's mission - which determines and characterise all of congregational life (NGK 2013a:207).

TTL recognises the vital role of local congregations in mission and departs from a strong statement that local congregations are the frontiers and primary agents of mission (WCC 2013b:67). The changing landscape calls for local congregations to take the lead, to experiment and to shape new experiments in mission. Congregations must be constantly renewed and inspired by the Spirit of mission (WCC 2013b:67).

\section{New insights in the diaconal nature of the church}

The diaconal work of the church is intrinsically part of the missional nature of the church and grounded in the love of Jesus Christ. God's mission includes words and deeds. The kenotic life of Jesus and his self-sacrifice, as well as the Father's sending of the Son, is the very basis of all service. According to the framework document, this aspect of the church must be understood in a holistic manner and includes mercy ministries, eco-justice issues, participating in peace and reconciliation and justice ministries. All dimensions of the deaconate are ways to participate in God's mission to transform all of creation (NGK 2013a:207-208).

The WCC understands the church as a diaconal community and creates a very strong link between the missional nature of the church and its diaconal existence in communities. It must be noted that the main discussion on the diaconal nature of the church at the WCC in 2013 was in a separate policy document Theological perspectives on diakonia in the twenty-first century (WCC 2013a:103-112). This specific document will not be discussed, but the approach of the DRC to understand all dimensions of the deaconate as a way to participate in God's mission is clearly evident in the WCC document.

\section{Intermezzo}

The DRC document continues with a discussion of nine issues that can be regarded as a road map for the praxis of a missional church and the way in which policy can guide this. It provides a kind of index of the missional story about to unfold in the eventual praxis of the church.

\section{New insights in spirituality}

The very first theme is spirituality, and the document states that the church contains pilgrim people - people crossing borders and inviting others on the journey. Missional spirituality is spirituality for the road. Missional spirituality is a transformative spirituality, and the journey is one of transformation and being transformed. Missional spirituality is a spiritual awareness of God's presence and of life in the Trinity. It is a spirituality of the everyday, as all spirituality is missional spirituality (NGK 2013a:208).

TTL emphasises spirituality - the challenge is being stated as a quest of how the church can reclaim mission as transformative spirituality which is life-affirming? (WCC 2013b:52). The idea of transformative spirituality receives a lot of attention in TTL. It is not only about what the church of Christ do in mission but equally about how we life our mission (WCC 2013b):

Spirituality gives our lives their deepest meaning. It stimulates, motivates and gives dynamism to life's journey. It is energy for life in its fullness and calls for a commitment to resist all forces, powers and systems which deny, destroy and reduce life. (p. 57)

The point of convergence is that both documents recognise the importance of missional spirituality. Missional spirituality is transformative spirituality. The church in mission can only be sustained by spiritualities deeply rooted in the Trinity.

\section{New insights in church offices and leadership}

The church organises what it does and needs leadership to organise its praxis. The DRC is challenged to think in new ways about church leadership and the way in which offices function. The emphasis is on the priesthood of all believers and on all believers to participate in God's mission. They are the operational base of the missio Dei. The Holy Spirit empowers every believer to go forth and to be salt and yeast (NGK 2013a:209).

TTL has a brief statement that states that God empowers the church in mission, and participating in God's mission should be natural for all Christians (WCC 2013b:65).

\section{New insights in church planting}

The WCC affirms that today's changed world calls for local congregations to take new initiatives and that contextual ways of being church is particularly relevant to young people. It is vital that local congregations are constantly renewed and inspired by the Spirit of mission (WCC 2013b:66, 67).

The DRC document converges with TTL in stating that one of the core values of a missional church is to give birth to new faith communities. It expands on TTL by connecting this issue with the concept of kenosis, stating that a kenotic existence implies self-sacrifice so that new communities can be born. It must be part of a new missional discipline in the church. The church must use the opportunity presented by the network society to form new faith communities around new configurations of community in society. The DRC is called to think in new ways about church planting and remove restrictions in church polity (NGK 2013a:210-211). 


\section{New insights in liturgy}

Liturgy is the answer to God's call that flows out of the missio Dei as well as the way in which the church joins in with God's outward movement in mission. Liturgy is an exhibition of ecclesiology. This underscores the importance of a missional liturgy with the following characteristics (NGK 2013a:211):

- a liturgy focussed on God and supporting the conviction that the church participates in God's movement towards the world

- a liturgy that supports discernment and that assists God's people to encounter God in worship, leading to the appreciation of contextually relevant worship and liturgy

- a liturgy of life where worship flows into everyday life and liturgy reaches its full intent in everyday life.

The WCC states that our participation in mission, our being in creation and our practice of the life of the Spirit need to be woven together. The church is called to make present God's holy and life-affirming plan for the world revealed in Jesus Christ (WCC 2013b:55, 61).

\section{New insights in youth ministry}

Youth ministry must express and support the new insights in the missional nature of the church. The contextualisation of the Gospel in the life of the young faithful needs particular attention, and the values that support a missional understanding of the church must play an important role in the formation of young generations (NGK 2013a:212).

TTL refers to the relevance of contextual ways of being church for young people (WCC 2013b:66) but does not pay more particular attention to youth ministry as such.

\section{New insights in public witness}

The primary locus of public witness is found in everyday life where the people of God participate in the multitude of ways in which God's kingdom breaks through in life. All theology is public theology as salvation is for the whole of creation. The missional focus on the world and all of creation means that the church must place the interest of creation above the interest of the church (NGK 2013a:212).

The WCC's mission statement has many issues that pertain to the public witness of the church in the process of participating in God's life-giving mission. This includes 'unmasking the demons that exploit and enslave' and seeking justice (WCC 2013b:61). TTL underscores the importance of speaking with one voice and giving common witness and an account of the hope that is in us (WCC 2013c:65).

\section{New insights in theological training}

The framework document defines leadership as the transformation of people and institutions, called by God, to participate in God's mission. Leaders must equip the people of God to reach out to each other and the world. Theological training must support this focus on missional leadership and must attend to the following (NGK 2013a:213):

- a theological understanding of discernment and formation that supports a life of discernment

- competencies to understand and cultivate cultural change in a congregation

- insight in networks, communal discernment and teamwork

- understanding congregational and cultural transformation

- nurturing competence to imagine God's preferred future and to be able to guide people en route to God's preferred future

- a focus on innovation and creativity

- the formation of a missional spirituality.

The issue of theological formation was also brought before the 2013 General Synod by way of a report of the joint curatorium (NGK 2013a:263). The report recognises that ecclesiology plays a very important role in theological formation and states that the underlying concepts of a missional church must determine policy in this regard (NGK 2013a:265).

\section{New insights in church order}

The report concludes with a number of statements on church polity and church order. The missional identity of the church determines ecclesiology and thus the way in which the church is being organised. Two concepts come into play the missional and the confessional identity of the church. The report pleads to include the missional identity in a formulation of the identity of the church in the church order.

\section{The new missional ecclesiology in the Dutch Reformed Church and the current ecumenical discourse}

The new policy document of the DRC shows remarkable convergence with the mission affirmation of the WCC, Together towards life. The understanding of mission and the missional ecclesiology of the DRC echoes ecumenical ideas on these issues. To answer the research question 'Where does the Dutch Reformed Church in South Africa (DRC) stand in relation to these issues?', it is clear that the DRC finds itself within the current ecumenical discourse on church and mission and sees the church as missional by its very nature.

Recent developments, and especially policy decisions made at the 2013 General Synod of the DRC, lead the researcher to conclude that the DRC does have a comprehensive and fully fledged missional ecclesiology, firmly imbedded in a contextual reformed theology and ecclesiology. This missional understanding means that the church is mission and participates in the missio Trinitatis. The question, 'Does the DRC have a formulated missional ecclesiology and is this ecclesiology ecumenically relevant?', can thus be answered 
as follows. Yes, the Framework document on the missional nature and calling of the DRC represents a well-formulated missional ecclesiology, and there is surprising convergence with a multitude of affirmations in the WCC policy document Together towards life. Both of these documents create missional language and stimulate a missional imagination of the church.

\section{From missional ecclesiology to missional polity}

Dingemans (1987:168) describes the church as a house, a home to live in. Church polity gives structure to this house. The missional character of the church must be reflected in church polity (Koffeman 2014:8).

Good governance means that the organisation of the church must reflect the identity of the church and must facilitate a situation where the way in which the church participates in God's mission brings life to all of creation. The DRC's General Synod of 2013 showed good governance by accepting a framework document to express the missional nature and character of the church. A number of significant changes in the DRC church governance (Church Order) also accompanied the acceptance of the framework document.

The framework document recommended a statement on both the confessional as well as the missional nature of the church as is the case in the Reformed Church in America (GranbergMichaelson 2008:263-282).

\section{Article 1}

In the case of the 2013 Church Order (NGK Church Order 2013c:1), Article 1 describes the confession and order of the DRC. A new Article 2, describing the missional nature of the DRC, has been added:

The Dutch Reformed Church is called by the Triune God to participate in God's mission in the world. The Church is equipped by the Holy Spirit to serve God's honour and to proclaim the ministry of reconciliation and salvation of Christ.

\section{Article 9}

Article 9 describes the office or ministry of the minister of the Word. Two additions to Article 9.4 were passed - on the issues of 'discernment and church planting'. Discernment is important because 'discernment is the first act of mission'.

The motivation to add 'church planting' to the responsibilities of the Minister of the Word was to add this essential aspect of a missional church to the responsibilities of ministers. The report states that church plating is the discipline to form new faith communities as a way of participating in God's mission and to serve as an expression and sign of God's kingdom. Both proposals were incorporated in Article 9.4 of the Church Order of 2013.

\section{Article 10}

Article 10 regulates the territorial principle and states:

A Minister of the Word may not perform any official duties (Article 9) within the boundaries of another congregation without the permission of its church council.

At the DRC's General Synod in 2011, the synod accepted the following formulation and change to Article 10:

A Minister of the Word may not perform any official duties (Article 9) amongst the members of another congregation without the permission of its church council.

The amendment was motivated as a change in the geographical limitations on the work of a minister of the Word. This change will facilitate the formation of new communities and church planting.

\section{Article 16}

Article 16 covers the office of elder and was modified to add the concept of spiritual discernment to the understanding of the office of eldership.

\section{Article 53}

Article 53 was amended to include a new formulation on the mission of God and reads:

53.1 The mission of the Triune God, Father, Son and Holy Spirit is to give life in fullness to the world, and the church serves God's mission by participating in this through mission work.

Article 53.4 is also significant as it states:

Every congregation is a missional church and every member a missionary. Every member and each congregation is called into mission. Where the scope of the work and other circumstances demand it, the work is done by broader denominational structures.

\section{Conclusion}

The new policy document of the DRC shows remarkable convergence with TTL, and the DRC finds itself within the current ecumenical discourse on church and mission. On a policy level, the DRC does have a comprehensive and fully fledged missional ecclesiology, firmly imbedded in a contextual reformed theology and ecclesiology. This means that the DRC understands the church as missional by its very nature. This missional understanding also sees the church as mission and as participating in the missio Trinitatis. The DRC shows good governance in the sense that it has embarked on a process to revise the church order in the light of the policy decisions and in the sense of the foundation laid by revising a number of important articles of the church order. Church polity is informed by a missional understanding of being church.

A missional approach affirms life in its fullness and supports the flourishing of creation. The deduction was that good 
governance in society entails a society where justice is practised, sustainable lifestyles propagated and respect for the earth practised, particularly in the liturgy of the church. This means that the DRC, with a missional understanding of being church, can benefit in its discernment processes and prophetic witness by using the following hermeneutical key in its participation in good governance: Wherever life in its fullness and in all its dimensions is affirmed, including the liberation of the oppressed, the healing and reconciliation of broken communities and the restoration of the creation, the church discern the Spirit of God bringing life. Wherever forces of death and destruction of life prevail, the church discerns opposition to God's life-giving mission.

The DRC finds itself, together with a broader ecumenical community, on a journey towards life. It does have an appropriate basis for good governance in church and society.

\section{Acknowledgements \\ Competing interests}

The author declares that he has no financial or personal relationships which may have inappropriately influenced him in writing this article.

\section{References}

Bevans, S., 2010, 'From Edinburgh to Edinburgh: Towards a missiology for a world church', in O.U. Kalu, P. Vethanayagamony \& E.K-F. Chia (eds.), Mission after Christendom: Emergent themes in contemporary mission, pp. 1-11, Westminster John Knox, Louisville.

Bevans, S.B. \& Schroeder, R.P., 2004, Constants in context: A theology of mission for today, Orbis, Maryknoll.

Bevans, S.B. \& Schroeder, R.P., 2011, Prophetic dialogue: Reflections on Christian mission today, Orbis, Maryknoll.

Branson, M.L., 2007, 'Ecclesiology and leadership for the missional church', in G van Gelder (ed.), The missional church in context, pp. 94-125, Eerdmans, Grand Rapids.

Coetzee, M.H. \& Conradie, E.M., 2012, 'Dominante teologiese sleutels in die Ned Geref Kerk na 1974', Nederduitse Gereformeerde Teologiese Tydskrif 53 (3/4) 90-108.

Dingemans, G.D.J., 1987, Een huis om in te wonen: Schetsen en bouwstenen voor een Kerk en een Kerkorde van de toekomst, Uitgeverij Boekencentrum, 's-Gravenhage.

Dreyer, W., 2014, 'New context, new church order', in L.J. Koffeman \& J. Smit (eds.), Protestant church polity in changing contexts II: Case studies. Proceedings of the International Conference, Utrecht, The Netherlands, 07-10 November 2011 pp. 33-45, Lit Verlag, Zurich.

Evangelii Gaudium, 2013, Apostolic Exhortation Evangelii Gaudium of the Holy Father Francis to the bishops, clergy, consecrated persons and the lay faithful on the proclamation of the Gospel in today's world, Rome, Vatican Press.
Flett, J.G., 2010, The witness of God: The Trinity, Missio Dei, Karl Barth and the nature of Christian community, Eerdmans (Kindle edition), Grand Rapids.

Granberg-Michaelson, W., 2008, 'Insights into becoming a missional denomination', in C. van Gelder (ed.), The missional church and denominations: Helping congregations develop a missional identity, pp. 263-282, Eerdmans, Grand congregat
Rapids.

Koffeman, L.J., 2012, Het goed recht van die kerk: Een theologische inleiding op het kerkrecht, Leo J Koffeman (herdruk).

Koffeman, L.J., 2014, 'The dark side of the good news?: A theological approach to church polity', in A.L. Jannsen \& L.J. Koffeman (eds.), Protestant church polity in changing contexts I: Ecclesiological and historical contributions. Proceedings of the International Conference, Utrecht, The Netherlands, 7-10 November 2011 pp. 1-16, Lit Verlag, Zurich.

Nederduitse Gereformeerde Kerk (NGK), 2002a, Agenda van die Algemene Sinode van die Nederduitse Gereformeerde Kerk 2002, 13-19 Oktober 2002.

Nederduitse Gereformeerde Kerk (NGK), 2002b, Handelinge van die Algemene Sinode van die Nederduitse Gereformeerde Kerk 2002, 13-19 Oktober 2002.

Nederduitse Gereformeerde Kerk (NGK), 2004, Agenda van die Algemene Sinode van die Nederduitse Gereformeerde Kerk 2004, 10-16 Oktober 2004.

Nederduitse Gereformeerde Kerk (NGK), 2007a, Agenda - Deel 1 van die Algemene Sinode van die Nederduitse Gereformeerde Kerk 2007, 04-08 Junie 2007.

Nederduitse Gereformeerde Kerk (NGK), 2007b, Die Kerkorde van die Nederduitse Gereformeerde Kerk, LuxVerbiBM, Wellington.

Nederduitse Gereformeerde Kerk (NGK), 2011a, Agenda vir die 14de vergadering van die Algemene Sinode van die Nederduitse Gereformeerde Kerk 2011, Oktober 2011.

Nederduitse Gereformeerde Kerk (NGK), 2011b, Handelinge van die 14de vergadering van die Algemene Sinode van die Nederduitse Gereformeerde Kerk 2011, 10-14 Oktober 2011.

Nederduitse Gereformeerde Kerk (NGK), 2013a, Agenda vir die 15de vergadering van die Algemene Sinode van die Nederduitse Gereformeerde Kerk 2013, 06-10 Van die Algemento 2013.

Nederduitse Gereformeerde Kerk (NGK), 2013b, Notule van die 15de vergadering van die Algemene Sinode van die Nederduitse Gereformeerde Kerk, 06-10 Oktober 2013.

Nederduitse Gereformeerde Kerk (NGK), 2013c, Die Kerkorde van die Nederduitse Gereformeerde Kerk, viewed 06 March 2013, from http://www.ngkerkas.co.za/ wp-content/uploads/2013/04/KERKORDE-2013.pdf

Niemandt, C.J.P., 2010, 'Kontoere in die ontwikkeling van 'n missionêre ekklesiologie in die Nederduitse Gereformeerde Kerk: 'n Omvangryker vierde golf', Nederduitse Gereformeerde Teologiese Tydskrif 5(3/4), 92-103.

Niemandt, N., 2013, Nuwe leiers vir nuwe werklikhede, CUM, Vereniging.

Niemandt, N., 2014, 'Emerging missional ecclesiology in the Dutch Reformed Church in South Africa and church polity', in A.L. Jannsen \& L.J. Koffeman (eds.), Protestant church polity in changing contexts I: Ecclesiological and historical contributions. Proceedings of the International Conference, Utrecht, The Netherlands, 07-10 November 2011, pp. 65-81, Lit Verlag, Zurich.

Roxburgh, A.J., 2011, Missional: Joining God in the neighborhood, Baker, Grand Rapids. Taylor, C., 2004, Modern social imaginaries, Duke University, Durham.

Van Gelder, C., 2007, The ministry of the missional church: A community led by the Spirit, Baker, Grand Rapids.

World Council of Churches, 2013a, Theological perspectives on diakonia in the twentyfirst century, in World Council of Churches, Resource book WCC 10th Assembly, Busan 2013, pp. 103-112, World Council of Churches Publications, Geneva.

World Council of Churches, 2013b, Together towards Life: Mission and evangelism in changing landscapes, in World Council of Churches, Resource book WCC 10th Assembly, Busan 2013, pp. 51-76, World Council of Churches Publications, Geneva. 